\title{
GONOCOCCAL ENHANCEMENT OF STAPHYLOCOCCAL VIRULENCE FOR THE MOUSE
}

\author{
J. FLYNN AND M. G. MCENTEGART \\ Department of Medical Microbiology, University of Sheffield
}

WHEN mixed cultures of Staphylococcus aureus and Proteus vulgaris are inoculated intraperitoneally into mice, the staphylococcus apparently enhances the virulence of the proteus and fulminating proteus infections are produced, although pure cultures of the same organisms may be given by the same route without effect (Arndt and Ritts, 1961; Arndt, Young and Ritts, 1963). As we had failed, despite the use of various methods of immunosuppression, to induce any gonococcal infection in a small laboratory animal, we used an approach similar to that of these workers to see whether $S$. aureus given simultaneously with Neisseria gonorrhoeae would enhance the virulence of the gonococcus for mice when both organisms were given intraperitoneally. This study showed that the reverse effect occurs.

\section{MATERIALS AND METHODS}

Experimental animals. Swiss Webster mice ranging in weight from 12-15 $\mathrm{g}$ were fed on Diet 86 (Oxoid) and water was provided ad libitum. They were caged in groups of ten.

Bacterial cultures. The strains of $N$. gonorrhoeae used were of type I, freshly isolated from patients attending the Venereal Disease Clinic, Sheffield, or were laboratory strains of type IV (Kellogg et al., 1963). The S. aureus was a typical coagulase-positive strain freshly isolated from a patient at the Children's Hospital, Sheffield.

Preparation of inocula. The staphylococcus strain was stored on Dorset egg medium at $4^{\circ} \mathrm{C}$ and when required as inoculum was grown in Lab-Lemco broth for $14 \mathrm{hr}$, centrifuged and washed three times in phosphate-buffered saline, $p \mathrm{H}$ 7.3. The deposit was resuspended in $10 \mathrm{ml}$ phosphate buffer at the same $p \mathrm{H}$ and the turbidity of the suspensions was measured in an EEL nephelometer. The approximate bacterial count was estimated by reference to previously prepared graphs and adjusted to give an expected count of $2 \times 10^{7}$ per $\mathrm{ml}$. These counts were confirmed by the method of Miles, Misra and Irwin (1938).

Gonococcal cultures were grown at $37^{\circ} \mathrm{C}$ in 5 per cent. $\mathrm{CO}_{2}$ for $14 \mathrm{hr}$ on Difco GC Medium Base plus 2 per cent. supplement (White and Kellogg, 1965). At the end of this period the organisms were scraped off and washed with centrifugation three times in phosphate-

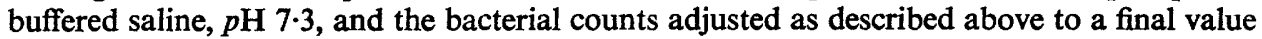
of $1.6 \times 10^{7}$ per ml. Before inoculation into mice the bacteria were again centrifuged and resuspended in a suitable volume of tissue-culture medium no. 199 to permit the administration of any necessary total dose of organisms without exceeding a volume $0.5-1 \mathrm{ml}$.

Killed gonococci. Standardised suspensions were killed by heating at $80^{\circ} \mathrm{C}$ for $10 \mathrm{~min}$.

Gonococcal endotoxin. This was prepared by the method of Maeland (1968) and its activity tested by the production of a Schwartzman reaction in the skin of a rabbit.

Immunisation of mice against staphylococcal infection. In the first experiment fatal staphylococcal infections occurred in all the mice inoculated simultaneously with staphylococci and gonococci. A group of mice was therefore immunised against staphylococci with the object of preventing such infections, in the hope that survivors might develop 
gonococcal infection. The mice were given intraperitoneally two doses each of $0.5 \mathrm{ml}$ of a saline suspension of live staphylococci $\left(2 \times 10^{7}\right.$ per $\left.\mathrm{ml}\right)$, with an interval of 7 days, because the work of Ekstedt (1963) suggested that this was a suitable dose for immunisation. Two weeks later, as a part of expt 2 , the mice were challenged with a mixture of staphylococci and gonococci as recorded in table $\mathrm{I}$.

Experimental design. In the first experiment, three groups of ten mice were given respectively staphylococci alone, gonococci alone and staphylococci with gonococci (expt 1). This experiment was repeated with the addition of a further group of mice immunised against staphylococci (expt 2).

After we had established the effect of the joint challenge, the optimum dosage was assessed by means of a "chessboard" titration in which groups of ten mice and ten-fold dilutions of organisms of each species on either " axis "were used (expt 3). The optimum dose of a suspension of one species was taken to be the least number producing 100 per cent. mortality when infected with an adequate dose of the other.

TABLE I

The fate of mice challenged intraperitoneally with Staphylococcus aureus and Neisseria gonorrhoeae

\begin{tabular}{cccc}
\hline Group & $\begin{array}{c}\text { Immune status } \\
\text { of mice }\end{array}$ & Challenge with & $\begin{array}{c}\text { Number of deaths } \\
\text { after } 48 \mathrm{hr}\end{array}$ \\
\hline 1 & Normal & gonococci* & 0 \\
2 & Normal & staphylococci & 0 \\
3 & Normal & $\begin{array}{c}\text { gonococci and } \\
\text { staphylococci }\end{array}$ & $10 \dagger$ \\
4 & Immune + & $\begin{array}{c}\text { gonococci and } \\
\text { staphylococci }\end{array}$ & 0 \\
\hline
\end{tabular}

* Dosage of organisms, whether given alone or in combination: gonococci $8 \times 10^{6}$; staphylococci $4 \times 10^{6}$. Ten mice in each group.

$\dagger$ All deaths due to staphylococcal infection: no gonococci isolated.

$\ddagger$ Animals given intraperitoneal injections of live staphylococci in two doses $1 \mathrm{wk}$ apart; challenge 2 wk after the second injection.

In the 4th experiment, these optimum doses were used to investigate the effect on the mortality of mice when consecutive intraperitoneal injections of $S$. aureus and $N$. gonorrhoeae were given at increasing intervals. The order of administration was reversed and the effects of increasing intervals again noted. Type-I and type-IV strains of gonococci were next investigated. Killed gonococci were tested in place of live organisms, and gonococcal endotoxin used in place of gonococci.

In the final study (expt 5) serial white-cell counts over a 2-day period were carried out on the blood of six mice from each group of ten. The groups were $(a)$ normal controls, (b) mice receiving gonococci alone, $(c)$ staphylococci alone, $(d)$ gonococci and staphylococci, and $(e)$ gonococcal endotoxin.

\section{RESULTS}

The results of experiment 2 are given in Table I which shows that in the intraperitoneal dosage used neither gonococci alone (group 1) nor staphylococci alone (group 2) had any obvious ill effects upon mice. In the nonimmunised (group 3) the simultaneous administration of $S$. aureus and gonococci produced 100 per cent. mortality within 2 days. Cultures of the heart, 
blood, liver and spleen showed that these mice had died from a staphylococcal infection; $N$. gonorrhoeae was not isolated. These results were similar to

TABLE II

The fate of mice inoculated intraperitoneally with Staphylococcus aureus and

Neisseria gonorrhoeae given simultaneously in varied dosage

\begin{tabular}{|c|c|c|}
\hline \multicolumn{2}{|c|}{ Challenge dose of } & \multirow{2}{*}{$\begin{array}{c}\text { Number of deaths* } \\
\text { after } 48 \mathrm{hr}\end{array}$} \\
\hline gonococci & staphylococci & \\
\hline $1.2 \times 10^{7}$ & $\begin{array}{l}4 \times 10^{7} \\
4 \times 10^{6} \\
4 \times 10^{5} \\
4 \times 10^{4}\end{array}$ & $\begin{array}{r}10 \\
10 \\
4 \\
0\end{array}$ \\
\hline $\begin{array}{l}1 \cdot 2 \times 10^{7} \\
1 \cdot 2 \times 10^{6} \\
1 \cdot 2 \times 10^{5} \\
1 \cdot 2 \times 10^{4}\end{array}$ & $4 \times 10^{7}$ & $\begin{array}{r}10 \\
2 \\
0 \\
0\end{array}$ \\
\hline
\end{tabular}

* Deaths in groups of ten mice after inoculation with combinations of different doses of both species of cocci. This table is a shortened record of a larger " chessboard" titration; it represents all the relevant data of the experiment covering the range between 100 per cent. and nil mortality.

those of experiment 1 . The mice protected against staphylococcal infection by immunisation (group 4) showed no evidence of gonococcal infection when challenged with both species. The simultaneous administration of live staphylococci did not therefore induce susceptibility to gonococci in these mice.

TABLE III

The effect on the mortality of mice of varying the time interval between consecutive intraperitoneal injections of Staphylococcus aureus and Neisseria gonorrhoeae

\begin{tabular}{ccc}
\hline $\begin{array}{c}\text { Order of injection } \\
\text { of organisms* }\end{array}$ & $\begin{array}{c}\text { Time between first } \\
\text { and second } \\
\text { injections (hr) }\end{array}$ & $\begin{array}{c}\text { Number of deaths } \dagger \\
\text { after } 48 \mathrm{hr}\end{array}$ \\
\hline Staphylococci first, & 2 & 10 \\
then gonococci & 4 & 2 \\
& 6 & 0 \\
Gonococci first, then & 8 & 0 \\
staphylococci & 4 & 10 \\
& 12 & 10 \\
& 24 & 10 \\
& 36 & 3 \\
& 48 & 0
\end{tabular}

* Groups of ten mice received separate injections of each species in the order and at the timeintervals shown. Inoculum sizes: staphylococci $4 \times 10^{6}$; gonococci $1 \cdot 2 \times 10^{7}$.

$\dagger$ Of ten mice.

Quantitative aspects of this study (expt 3) are shown in table II, which records the significant results taken from larger experiments in which the dose of gonococci on one axis was varied by log amounts against similar variations in 
the doses of staphylococci on the other axis. Only the results covering the range from 100 per cent. mortality to a nil mortality are given. The optimum dose of gonococci was $1.2 \times 10^{7}$ because a reduction in dosage was accompanied by a reduced mortality. In the same way the optimum dose of staphylococci was found to be $4 \times 10^{6}$.

The effects of injecting the optimum dose of each species separately, giving one at different time-intervals before or after the other (expt 4), are shown in table III. When staphylococci were given first, the introduction of gonococci

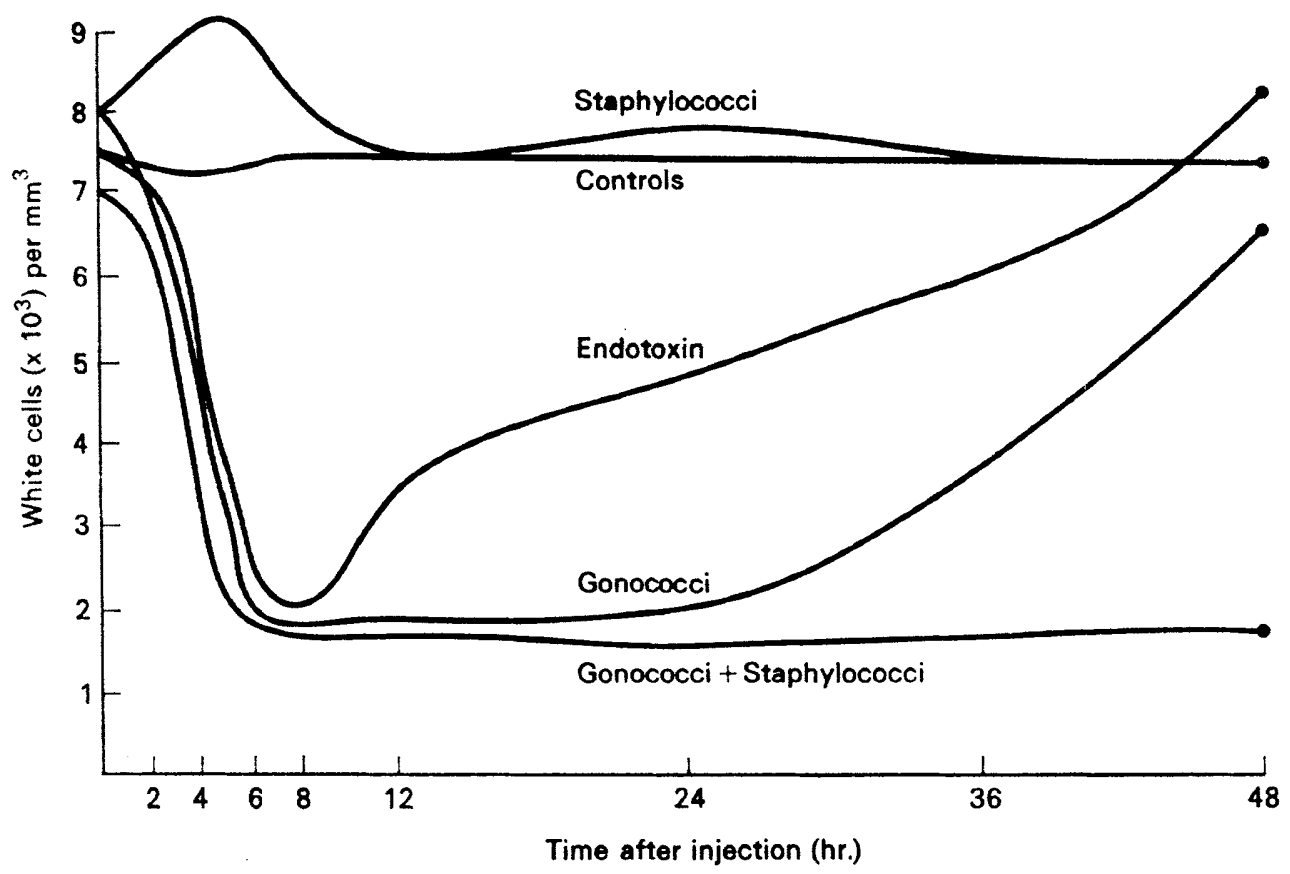

FIGURE.-The blood white-cell counts of mice after the intraperitoneal injection of Staphylococcus aureus and Neisseria gonorrhoeae, alone or in combination, or of gonococcal endotoxin, compared with counts in normal mice. Means of values from six mice in each group of ten.

$2 \mathrm{hr}$ later was uniformly fatal, but not so with a 4-hr interval; but when gonococci were given first, fatal staphylococcal infections occurred in all the mice challenged with staphylococci up to $24 \mathrm{hr}$ later. Some mice died even when the interval was $36 \mathrm{hr}$ and it was only after $48 \mathrm{hr}$ that there was no mortality.

Because these results indicated that $N$. gonorrhoeae could potentiate infection by sublethal doses of staphylococci to a lethal level, a parallel experiment was carried out to compare type-IV strains with those of type I. There was no demonstrable difference, both having the same potentiating effect. The substitution of killed gonococci did not alter the results, and finally it was demonstrated that gonococcal endotoxin ( $200 \mu \mathrm{g}$ per mouse) also potentiated fatal staphylococcal infection.

The effects on leucocyte counts of mice of the various challenges $(b)$ to $(e)$ in experiment 5, compared with normal controls $(a)$ are shown in the figure. 
These are average values from samples from six mice, or latterly from a smaller number of surviving mice when this fell below six. The figure shows that injection of staphylococci induced a minor and transient increase in white-cell counts. On the other hand, endotoxin, gonococci alone, or gonococci with staphylococci produced a profound leucopenia within 4-6 hr. Recovery from the endotoxin effect was marked at $24 \mathrm{hr}$, and was complete at $48 \mathrm{hr}$; recovery from the effect of gonococci alone was delayed until after $24 \mathrm{hr}$, and after injection of both gonococci and staphylococci leucopenia was still present at $48 \mathrm{hr}$.

\section{Discussion}

Although the simultaneous administration of staphylococci has a potentiating effect on the virulence of Proteus in mice (Arndt and Ritts, 1961), no comparable effect could be demonstrated when staphylococci were given in combination with gonococci, even when mice were immunised so as to permit large doses of staphylococci being given. Indeed, the unexpected finding was a reversal of roles in that injection of gonococci greatly increased the susceptibility of mice to $S$. aureus. Delaunay et al. (1944) showed that injection of sub-lethal doses of lipopolysaccharide fraction from salmonellae, Bacillus anthracis or staphylococci reduced the resistance of mice and guinea-pigs to non-lethal doses of staphylococci. Schaedler and Dubos (1957) demonstrated that the injection of killed B.C.G., pertussis vaccine, or the purified lipopolysaccharide endotoxin of Gram-negative bacilli was capable of converting chronic bacterial infections in mice into acute ones. Conti et al. (1961) showed that intracutaneous or intravenous injection of bacterial endotoxin increased the infectivity of pathogenic staphylococci in the skin of the rabbit, the area being characterised by the absence of leucocyte infiltration. On the other hand, Whitby and Rowley (1959) recorded that organisms that were opsonised with specific antibody before injection into the mouse were rapidly destroyed in vivo and in vitro by peritoneal macrophages. This accords with our finding that mice protected by previous active immunisation with staphylococci could no longer be made susceptible to staphylococcal challenge by the administration of endotoxin.

The outcome of intraperitoneal infection in the mouse depends on the efficiency of phagocytosis by the polymorphonuclear leucocytes and macrophages of the peritoneum and subsequent destruction of the organisms. Mulholland and Cluff (1964) demonstrated that migration of leucocytes into the peritoneal cavity of rabbits with staphylococcal peritonitis could be inhibited by pretreatment with endotoxin. The phagocytic capacity of the leucocytes was found to be the same as in normal blood. In our mice gonococcal endotoxin rapidly induced leucopenia, and it seems clear that endotoxin acts by depressing the cellular defence mechanism in the early stages of infection. This would explain the results shown in table III: gonococcal depression of the defence mechanism of the host for some 24 to $36 \mathrm{hr}$ allows fatal staphylococcal infection to occur, but when staphylococci are given first they are removed and destroyed within $4 \mathrm{hr}$, after which time gonococcal challenge is too late to effect potentiation of their virulence. 


\section{SumMary}

Although the simultaneous administration of staphylococci enhances the virulence for mice of certain Gram-negative bacilli, no such enhancement of virulence of gonococci could be demonstrated. On the contrary, the virulence of Staphylococcus aureus was enhanced by the simultaneous administration of gonococci, and fatal staphylococcal infections could be produced by normally non-lethal doses of staphylococci. However, mice were protected by previous immunisation with live staphylococci. The enhanced virulence of staphylococci is due to the action of gonococcal endotoxin on the cellular response of the mouse in the early stages of infection. The exact mechanism is not yet fully understood, but endotoxin administration produces leucopenia, and it is suggested that an important feature is the inhibiting effect of endotoxin on the migration of phagocytic cells to the site of infection.

We are grateful to the Medical Research Council for providing a grant in support of this investigation.

\section{REFERENCES}

ARNDT, W. F., AND RitTs, R. E. 1961. Synergism between staphylococci and proteus in mixed infection. Proc. Soc. Exp. Biol. Med., 108, 166.

ARndT, W. F., Young, E. J., AND RITTs, R. E. 1963. Staphylococcal enhancement of susceptibility to bacterial infection in the mouse. J. Infect. Dis., 112, 255.

Conti, C. R., Cluff, L. E., ANd Scheder, E. Patricia 1961. Studies on the pathogenesis of staphylococcal infection. IV. The effect of bacterial endotoxin. J. Exp. Med,, 113, 845.

Delaunay, A., Sarciron, R., AND Pages, J. 1944. Antigènes glucido-lipidiques et pouvoir phagocytaire des cellules réticulo-endothéliales. C.r. Séanc. Soc. Biol., 138, 345.

Ekstedt, R. D. 1963. Studies on immunity to staphylococcal infection in mice. I. Effect of dosage, viability, and interval between immunization and challenge on resistance to infection following injection of whole cell vaccines. J. Infect. Dis., 112, 143.

Kellogg, D. S., JR, Peacock, W. L., JR, Deacon, W. E., Brown, L., and Pirkle, C. I. 1963. Neisseria gonorrhoeae. I. Virulence genetically linked to clonal variation. $J$. Bact., 85, 1274.

MAELAND, J. A. 1968. Antigenic properties of various preparations of Neisseria gonorrhoeae endotoxin. Acta. path. microbiol. scand., 73, 413.

Miles, A. A., Misra, S. S., AND IRWIN, J. O. 1938. The estimation of the bactericidal power of the blood. J. Hyg., Camb., 38, 732.

Mulholland, J. H., AND ClufF, L. E. 1964. The effect of endotoxin upon susceptibility to infection: the role of the granulocyte. In Bacterial endotoxins, edited by M. Landy and W. Braun, New Brunswick, p. 211.

SchaEdleR, R. W., AND Dubos, R. J. 1957. Effects of cellular constituents of mycobacteria on the resistance of mice to heterologous infections. II. Enhancement of infection. J. Exp. Med., 106, 719.

Whitby, J. L., AND Rowley, D. 1959. The role of macrophages in the elimination of bacteria from the mouse peritoneum. Br. J. Exp. Path., 40, 358.

White, L. A., AND Kellogg, D. J., JR 1965. Neisseria gonorrhoeae identification in direct smears by a fluorescent antibody-counterstain method. Appl. Microbiol., 13, 171. 